Trichomycetes from China and the Description of Three New Smittium Species Author(s): D. B. Strongman and Shengquan Xu

Source: Mycologia, Vol. 98, No. 3 (May - Jun., 2006), pp. 479-487

Published by: Mycological Society of America

Stable URL: http://www.jstor.org/stable/20444725

Accessed: 17-06-2015 12:16 UTC

Your use of the JSTOR archive indicates your acceptance of the Terms \& Conditions of Use, available at http://www.jstor.org/page/ info/about/policies/terms.jsp

JSTOR is a not-for-profit service that helps scholars, researchers, and students discover, use, and build upon a wide range of content in a trusted digital archive. We use information technology and tools to increase productivity and facilitate new forms of scholarship. For more information about JSTOR, please contact support@jstor.org. 


\section{Trichomycetes from China and the description of three new Smittium species}

\author{
D.B. Strongman ${ }^{1}$ \\ Department of Biology, Saint Mary's University, \\ Halifax, Nova Scotia, B3H 3 C3 Canada \\ Shengquan $\mathrm{Xu}$ \\ College of Life Science, Shaanxi Normal University, \\ $X i$ 'an, PR China
}

\begin{abstract}
Trichomycetes were recovered from the guts of aquatic insect larvae collected from a stream in the Qinling Mountains in western China. These collections included Smittium hecatei, known only from Spain, as well as Smittium simulii and Stachylina penetralis, which appear to be more widely distributed. Caudomyces japonicus, previously recorded only from Japan, also is reported from crane fly larvae (Antocha sp.) from China. We describe three new species, Smittium chinliense from a tipulid host, as well as Smittium naiadis and Smittium nodifixum, both from chironomid larvae. A probable new species of Gauthieromyces was collected in mayfly nymphs and is illustrated but not described here.
\end{abstract}

Key words: aquatic insects, Caudomyces, Gauthieromyces, gut fungi, Harpellales

\section{INTRODUCTION}

Trichomycetes living in the guts of arthropods, mostly immature stages of insects in aquatic systems, are widely distributed. The best documented occurrences of these fungi are from the United States and western Europe (France, England and Spain) (Manier 1970, Moss et al 1975, Lichtwardt 1986, Santamaria 1997, Lichtwardt et al 2001, Valle and Santamaria 2004). Fewer published records exist for South America (Lichtwardt and Arenas 1996, Lichtwardt et al 2000), Central America (Lichtwardt 1994, 1997), Australia (Lichtwardt and Williams 1990) and New Zealand (Williams and Lichtwardt 1990). Although the Trichomycete survey to date has covered many widely separated continents, large areas with prime habitat and high arthropod diversity have yet to be examined in a systematic way (e.g. in Canada, Africa and China). The abundance and frequency of occurrence of Trichomycetes in hosts from areas that already have been surveyed suggest that sampling in new geographic areas will

Accepted for publication 1 Mar 2006.

${ }^{1}$ Corresponding author. E-mail: doug.strongman@smu.ca yield many undescribed species and may help better elucidate the ecology and biogeography of this fungal group.

Trichomycetes are poorly known from Asia. One publication reported species recovered in Japan (Lichtwardt et al 1987) and another describing parasites of blackflies from China noted the presence of a Trichomycete, Harpella melusinae Leger \& Dubosq, in these hosts (Adler et al 1996). Chien and Hsieh (2001) reported Trichomycetes in the orders Eccrinales and Asellariales from aquatic and terrestrial crustaceans as well as millipedes in Taiwan, including two new species of eccrinids from crustacean hosts.

This paper reports Trichomycetes from aquatic insects collected in the Niu Bei Liang nature protection area, Qinling Mountains approximately $40 \mathrm{~km}$ from Xi'an, in western China. We describe three new species of Trichomycetes in the genus Smittium from these collections as well as six other taxa of trichomycetes.

\section{MATERIAL AND METHODS}

Insects were collected in a D-net by kick-sampling (Lichtwardt et al 2001) in a fast-flowing, shallow stream (Hao River) in the Niu Bei Liang nature protection area, western China $\left(33^{\circ} 55.21 \mathrm{~N} 108^{\circ} 56.49 \mathrm{E}\right) 26$ and $27 \mathrm{Apr}$ 2005. The stream had a sandy and pebbly bottom with little organic material and flowed through an area of large boulders. The stream yielded immature stages of mayflies (Ephemeroptera), stoneflies (Plecoptera), larval flies (Diptera) and beetles (Coleoptera). Samples of tipulid (Diptera) larvae also were hand-picked from rocks in the splash zone of a small waterfall near the sampling area.

The hindgut and peritrophic matrix (in the dipterans) were dissected out of the hosts and examined microscopically for the presence of trichomycetes and other gut inhabitants. Fungal identifications were made with the Lucid keys available at the University of Kansas Trichomycete Website (www.nhm.ku.edu/fungi/). Semipermanent slides, stained with lactophenol cotton blue were prepared as described in Lichtwardt et al (2001). Digital photomicrographs of the diagnostic features were taken at the Saint Mary's University Taxonomy Laboratory, Halifax, Nova Scotia, Canada. Voucher specimens of new species and Caudomyces japonicus Lichtw. Kobayasi \& Indoh were deposited in the herbarium (SANU), College of Life Science, Shaanxi Normal University, Xi'an, 710062, Shaanxi, People's Republic of China. Other voucher specimens are in the collection of DBS, Saint Mary's University. 


\section{RESULTS}

The insects contained several species of Trichomycetes in the order Harpellales as well as protists in the genus Paramoebidium, which is currently classified within the Trichomycetes in the order Amoebidiales (Lichtwardt et al 2001). Harpellids recovered from midges (Diptera: Chironomidae) included Smittium hecatei L.G.Valle \& Santam. and Sm. simulii Lichtw. from the hindgut. Stachylina penetralis Lichtw. was observed on the peritrophic matrix of these hosts. In addition two species of Smittium collected in chironomids had unique morphological features that warrant description as new species, Sm. naiadis (FIGS. 1-4) and Sm. nodifixum (FIGS. 5-8). Thalli of Paramoebidium spp. were common in the hindgut of these dipterans but insufficient characters were available to identify them to species.

The other dipterans commonly collected were two unidentified species of tipulids (Antocha spp.), one from wet rocks next to a waterfall and another from the stream. Although approximately 50 larvae from the waterfall site were dissected no fungi were present in the hindgut. Only three specimens of another Antocha sp. were collected from the stream. One of these had thalli of a Smittium sp. that did not match any described species so we describe a new species, Sm. chinliense (FIGS. 9-11), below. Caudomyces japonicus (FIGS. 12, 13) was collected in the hindguts of two tipulid larvae, including one larva that also had Sm. chinliense. This monotypic genus was known only from Japan where it was recorded from the same genus of tipulid host (Lichtwardt et al 1987).

Mayflies collected from Hao River had Trichomycetes in their hindguts from the same orders (Harpellales and Amoebidiales) as the chironomids. A Gauthieromyces sp. was recovered from Baetiella ausobskyi Braasch (Ephemeroptera: Baetidae). The genus Gauthieromyces and the type species, $G$. microsporus Lichtw., were described formally by Lichtwardt (1983) based on the original description and drawings from Gauthier (1960). No type material exists, but based on the drawings in the original species description the specimens from China belong to Gauthieromyces. Its distinctive minute, horseshoeshaped trichospores could not be confused with any other described species. We collected this Gauthieromyces sp. from a baetid host, which is in the same family of insect that G. microsporus occurs (Gauthier 1960). J.K. Misra, (jitrachravi@sify.com pers comm) recently has discovered a Gauthieromyces sp. from India. Images from his collection compared with the specimen from China suggest they are the same fungus. Misra is describing a new species so we report the Chinese specimen simply as Gauthieromyces sp. and provide photomicrographs to show the features in this collection from China (FIGs. 14, 15). These baetids also had Paramoebidium spp. in their guts.

The guts of siphlonurid mayflies (Ephemeroptera: Siphlonuridae) contained Paramoebidium spp. Approximately 12 specimens of ephemerellid mayflies (Ephemerellidae) were dissected but no Trichomycetes were seen. One to three specimens each of nemourid stoneflies (Plecoptera: Nemouridae) and mayflies in the families Heptageniidae and Caenidae were dissected but the guts contained no fungi. The small number of these insects in the collections probably reflects their phenology and it may be that they would have Trichomycetes in the gut at a different time or stage in their development. Predacious beetle larvae were not dissected because predacious insects normally do not house Trichomycetes (Lichtwardt et al 2001).

\section{TAXONOMY}

Smittium naiadis Strongman et Shengquan $\mathrm{Xu}$, sp. nov. FIGS. 1-4

Thallus diffusus, ramis primariis e fasciculo simplici cellularum basalium muco velatarum orientibus; ramificatio secundaria per longitudinem et in extremis ramorum principalium valde verticillata. Trichosporae cylindricae longae angustaeque (34-36 $\times 2.5-3.5 \mu \mathrm{m})$, cum collo conspicuo breve $(3 \mu \mathrm{m})$ quod ut videtur 1-2 tumores plerumque habet. Trichosporae appendice singula tenui instructae. Zygosporae incognita. In proctodaeo larvarum Chironomidarum.

Thallus diffuse, primary branches arise from a simple cluster of basal cells covered with mucilage (FIGS. 1, 2), secondary branching strongly verticilliate along the length and at the end of the primary branches (FIG. 1). Trichospores cylindrical, long and narrow $(34-36 \times 2.5-3.5 \mu \mathrm{m})$ with a conspicuous, short $(3 \mu \mathrm{m})$ collar that commonly appears to have 1 or 2 thickenings (FIGS. 3, 4). Trichospores with a single, thin appendage. Zygospores not found. In hindgut of bloodworms (Chironomidae).

Etymology. from the Latin naias meaning from a nymph, referring to the source being the immature (larval) stage of the host.

Specimens examined. CHINA. SHAANXI PROVINCE: Hao River, Niu Bei Liang nature protection area, $33^{\circ} 55.21 \mathrm{~N}$ $108^{\circ} 56.49 \mathrm{E}$. Slide CHI-2 prepared from the hindgut of a chironomid larva collected 27 Apr 2005 (HOLOTYPE SANU).

Note. This slide also contains thalli and trichospores of Sm. nodifixum.

Commentary. The trichospores in Sm. naiadis are long and narrow compared to most other species of Smittium (www.nhm.ku.edu/fungi/). The tricho- 
Figs. 1-4. Smittium naiadis. 1. Thallus branching and holdfast characteristics. 2. Details of the holdfast (arrow). 3, 4. Trichospores. The arrows indicate apparent thickenings in collar. Bars $=20 \mu \mathrm{m}$.

spore collar has distinctive thickenings and this feature seems to be consistent, therefore diagnostic. Smittium gravimetallum Lichtw. Ferrington \& Hayford (Ferrington et al 2000) has narrow spores but in this species they are shorter on average and have a distinct swelling in the midregion, which is lacking in $\mathrm{Sm}$. naiadis. Another species with long spores is $\mathrm{Sm}$. elongatum Lichtw. but they are wider than in $\mathrm{Sm}$. 
FIGS. 5-8. Smittium nodifixum. 5. Thallus arising from bulbous holdfast (arrow). 6. Details of knobby holdfast and individual branches. 7. Trichospore showing campanulate collar. 8. Trichospore with single appendage. Bars $=20 \mu \mathrm{m}$. 
Figs. 9-11. Smittium chinliense. 9. Thallus with foot-like holdfast (arrow). 10, 11. Released trichospores. Bars $=20 \mu \mathrm{m}$. 
Figs. 12-13. Caudomyces japonicus. 12. Trichospores with long collars attached to fertile branch. 13. A single trichospore with long collar typical of the species. Bars = $20 \mu \mathrm{m}$.

naiadis, the holdfast in Sm. elongatum is inconspicuous (Lichtwardt 1972) whereas it is prominent and embedded in mucilage in this new species. There was no apparent coiling in the appendage as is described for Sm. elongatum. Smittium angustum M.C. Williams $\&$ Lichtw. has narrow spores but they are shorter and the thallus features differ greatly from Sm. naiadis (Lichtwardt and Williams 1992).

\section{Smittium nodifixum Strongman et Shengquan $\mathrm{Xu}$,} sp. nov.

FIGS. 5-8

Thallus compactus, ramis primariis e haptero conspicuo nodoso orientibus; ramificatio secundaria sparsa. Trichosporae subcylindricae, 26-29.5 $\times 5-$ $6 \mu \mathrm{m}$, cum collo campanulato 5-6 $\mu \mathrm{m}$ longo. Zygosporae incognitae. In proctodaeo larvarum Chironomidarum.
FigS. 14-15. Gauthieromyces sp. 14. Immature thallus showing sparse branching from swollen basal cell at arrow. 15. Terminal fertile branch with many horseshoe-shaped trichospores. Bars $=20 \mu \mathrm{m}$.

Thallus compact, primary branches arising from a conspicuous knobby holdfast, secondary branching sparse (FIGS. 5, 6). Trichospores subcylindrical 26$29.5 \times 5-6 \mu \mathrm{m}$ with a campanulate collar 5-6 $\mu \mathrm{m}$ long (FIGS. 7, 8). Zygospores not found. In hindgut of bloodworms and other midge species (Chironomidae).

Etymology. from the Latin nodos and fixum, meaning fasten with a knot, in reference to the conspicuous, knobby holdfast in this species.

Specimens examined. CHINA. SHAANXI PROVINCE: Hao River, Niu Bei Liang nature protection area, $33^{\circ} 55.21 \mathrm{~N}$ $108^{\circ} 56.49 \mathrm{E}$. Slide CHI-4 prepared from the hindgut of a chironomid larva collected 27 Apr 2005 (HOLOTYPE SANU).

Commentary. The spore dimensions in Sm. nodifixum overlap with nine described species in this genus (www.nhm.ku.edu/fungi/). However, when 
thallus features are considered along with spore shape and collar characteristics, the species can be separated. Smittium acutum Lichtw. \& Grigg and Sm. annulatum Lichtw. share some features with this new species but the holdfast structures differ; Sm. acutum has a flared collar (Lichtwardt and Grigg 1998), compared to a campanulate collar in Sm. nodifixum, and the spores of Sm. annulatum are smaller on average (Lichtwardt 1997). Smittium commune Lichtw. \& Grigg has variable spores (Lichtwardt and Grigg 1998) so the dimensions overlap substantially with $\mathrm{Sm}$. nodifixum. However the spores in $S m$. commune are ellipsoidal and shorter, on average, with a shorter collar so it can be differentiated from Sm. nodifixum on this basis. The new species resembles Sm. cylindrosporum Lichtw. \& Arenas but trichospores in that species have a conspicuous bulge in the middle and the branching pattern in the thallus differs (Lichtwardt and Arenas 1996). There is no mention of a distinctive holdfast in the description of Sm. cylindrosporum, which is a conspicuous feature in Sm. nodifixum.

Smittium chinliense Strongman et Shengquan Xu, sp. nov. FIGS. 9-11

Thallus e haptero conspicuo pediformi oriens; ramificatio sparsa, trichosporis 3-4 in terminiis ramorum fertilium typice formantibus. Trichosporae cylindricae vel subcylindricae, 28.5-36 $\times 5-6 \mu \mathrm{m}$, cum collo tubulari 5-6 $\times 4 \mu \mathrm{m}$ saepe sporam latitudine aequanti, appendice singula instructae. Zygosporae incognitae. In proctodaeo larvarum Tipulidarum.

Thallus arising from a conspicuous foot-like holdfast, branching sparse, typically with 2-4 trichospores forming at the tips of fertile branches (FIG. 9). Trichospores cylindrical to subcylindrical, 28.5-36 $\times$ 5-6 $\mu \mathrm{m}$ with a tubular collar $5-6 \times 4 \mu \mathrm{m}$, often as wide as the spore, with a single appendage (FIGS. 10, 11). Zygospores not found. In hindgut of crane fly larvae (Tipulidae).

Etymology. from Qinling (pronounced chin-lee) Mountains of China where the collections were made.

Specimens examined. CHINA. SHAANXI PROVINCE: Hao River, Niu Bei Liang nature protection area, $33^{\circ} 55.21 \mathrm{~N}$ $108^{\circ} 56.49 \mathrm{E}$. Slide CHI-13 prepared from the hindgut of a tipulid (Antocha sp.) larva collected 27 Apr 2005 (HOLOTYPE SANU).

Note. This slide also contains thalli and trichospores of Caudomyces japonicus.

Commentary. This fungus does not resemble any of the three species known from tipulid larvae, Sm. simulatum Lichtw. \& Arenas (Lichtwardt and Arenas 1996), Sm. simulii (Lichtwardt 1964) and Sm. tipulidarum M.C. Williams \& Lichtw. (Williams and
Lichtwardt 1987) (www.nhm.ku.edu/fungi/). The long, cylindrical trichospores of Sm. chinliense are similar in dimensions to Sm. elongatum and $\mathrm{Sm}$. cylindrosporum, both from dipteran larvae (chironomids), but the collar in these species is narrower than the spore (Lichtwardt 1972, Lichtwardt and Arenas 1996) whereas the collar in Sm. chinliense is as wide as the spore. Also the thallus in both known species has verticilliate branching whereas $\mathrm{Sm}$. chinliense does not.

\section{DISCUSSION}

This paper expands the known geographic range of several Trichomycete species to another continent, China, and describes three new species, Sm. naiadis, $\mathrm{Sm}$. nodifixum and Sm. chinliense. Smittium hecatei is a recently described species from Spain (Valle and Santamaria 2004) and the Chinese collection fits the trichospore size ranges and characteristics for both spores $\alpha$ and spores $\beta$ as described by these authors. We did not see the "elephant leg" basal cell that is typical for this species but the thallus characteristics match otherwise. Smittium simulii is a species that is widely distributed and common in chironomid larvae (Lichtwardt et al 2001) so it is not surprising that we collected it in these hosts from China as well. Stachylina penetralis has been reported from Japan as well as Europe (Lichtwardt et al 2001) suggesting it might have broad distribution.

Smittium is the largest, most widely distributed genus of Trichomycetes with more than 70 species described to date from a variety of insect hosts. Therefore typical morphological characteristics used to define species (e.g. spore dimensions) overlap greatly, which makes species identification challenging. This problem is further complicated by the occurrence of several dimorphic species that exhibit two distinct spore morphologies arising from the same thallus (Valle and Santamaria 2004, White and Lichtwardt 2004). Thallus characteristics such as the holdfast and a more standardized description of the branching patterns may help delineate taxa. More molecular studies like those described in Gottlieb and Lichtwardt (2001) will provide data on genetic relatedness that might help refine our interpretation of the significance of certain morphological characters and variation among species.

Caudomyces japonicus specimens recovered from Antocha sp. larvae in the Qinling Mountains matched the type species description well and are from the same genus of host (Lichtwardt et al 1987). This is an extension of the geographic range for this fungus and although we, like the authors on the original description, were unable to identify the host to species 
it might be an indication that the host and fungus are widespread in Asia. The original description of C. japonicus included an illustration but this second collection from China supplements the illustration by providing photomicrographs (FIGS. 12, 13), which might help other collectors recognize the species and give us a better understanding of the morphological variation within the species.

The discovery of another species of Gauthieromyces is significant in that this monotypic genus has not been reported since its description from France in 1960 (Lichtwardt 1983). No type material exists for $G$. microsporus and subsequent attempts to collect the species at the type locality were unsuccessful (Lichtwardt 1983). The characteristics of the Gauthieromyces sp. from China differ from the type in that the swollen basal cell is shorter, tapers to the central axis more abruptly (FIG. 14) and the branching is more profuse with typically many spores (20+) per fertile branch (FIG. 15). The structure of the thallus is similar to species of Graminella, also known from baetid mayflies (www.nhm.ku.edu/fungi/). However the trichospores are diagnostic in that no other genus contains species with small, horseshoe-shaped spores. The spores in the Chinese collection are the same length around the curve $(10-12[-14] \mu \mathrm{m})$ as the type and about $2 \mu \mathrm{m}$ wide; no width is given in the original description (Lichtwardt 1983). The independent discovery of another species in both India and China provides reference material that will be useful when other species are found. The results from this limited survey of two habitats along a short stretch of one river suggest that China and other unexplored areas in Asia are rich in Trichomycetes and no doubt more extensive surveys will add many more new taxa.

\section{ACKNOWLEDGMENTS}

We thank Dr Zhezhi Wang, dean of the College of Life Science, Shaanxi Normal University (SNNU), for financing the field trip to the Qinling Mountains, and both SNNU and Saint Mary's University for financing travel for DBS. We thank Dr Zhongmin Dong, Biology Department, Saint Mary's University, for arranging the visit (by DBS) to China and for aiding the communication that helped to produce this manuscript. Mr Yi Bai and Ms Deng Sufang ably assisted us in the field. Carolyn Bird provided the Latin diagnosis. We also thank Dr R.W. Lichtwardt and Dr M.M. White for their help and discussions surrounding Smittium species and for editorial suggestions on the paper.

\section{LITERATURE CITED}

Adler PH, Wang Z, Beard CE. 1996. First records of natural enemies from Chinese blackflies (Diptera: Simuliidae). Med Entomol Zool 47:291-292.
Chien C-Y, Hsieh Li-H. 2001. Occurrence of Trichomycetes in Taiwan. In: Misra JK, Horn BW, eds. Trichomycetes and other fungal groups. Enfield, New Hampshire: Science Publishers Inc. p 55-72.

Ferrington Jr. LC, Lichtwardt RW, Hayford B. 2000. Smittium gravimetallum (Trichomycetes: Harpellales), a new species of gut fungus from Dicrotendipes fumidus (Johannsen) (Diptera: Chironomidae) in a metal-polluted stream. In: Hoffrichter O, ed. Late 20th century research on Chironomidae: an anthology from the 13th International Symposium on Chironomidae. Aachen, Germany: Shaker Verlag. p 253-257.

Gauthier M. 1960. Un nouveau Trichomycète rameux parasite des larves de Baëtis pumilus (Burm.). Travaux du Laboratoire d' Hydrobiologie et de Pisciculture de l' Université de Grenoble 50-51:225-227.

Gottlieb AM, Lichtwardt RW. 2001. Molecular variation within and among species of Harpellales. Mycologia 93:66-81.

Lichtwardt RW. 1964. Axenic culture of two new species of branched Trichomycetes. Am J Bot 51:836-842.

. 1972. Undescribed genera and species of Harpellales (Trichomycetes) from the guts of aquatic insects. Mycologia 64:167-197.

. 1983. Gauthieromyces, a new genus of Harpellales based on Genistella microspora. Mycotaxon 17:213215.

- 1986. The Trichomycetes: fungal associates of arthropods. New York: Springer-Verlag. 343 p.

- 1994. Trichomycete fungi living in the guts of Costa Rican phytotelm larvae and other lentic dipterans. Rev Biol Tropical 42:31-48.

- 1997. Costa Rican gut fungi (Trichomycetes) infecting lotic insect larvae. Rev Biol Tropical 45: 1339-1383.

-, Arenas J. 1996. Trichomycetes in aquatic insects from southern Chile. Mycologia 88:844-857.

, Cafaro M, White MM. 2001. The Trichomycetes: fungal associates of arthropods. http://www.nhm. ku.edu/\%7Efungi/Monograph/Text/Mono.htm

- Grigg RD. 1998. Four new Smittium species inhabiting the hindgut of Chironomidae larvae. Mycologia 90:427-433.

— Kobayasi Y, Indoh H. 1987. Trichomycetes of Japan. Trans Mycol Soc Japan 28:359-412.

—_, López Lastra C, Mazzucchelli MG. 2000. Fungi living in the guts of larval aquatic insects in northwestern Argentina. Mycologia 92:332-340.

- Williams MC. 1990. Trichomycete gut fungi in Australian aquatic larvae. Can J Bot 68:1057-1074.

1992. Western Australian species of Smittium and other Trichomycetes in aquatic insect larvae. Mycologia 84:392-398.

Manier J-F. 1970. Trichomycètes de France. Annales des Sciences Naturelles Botanique, Paris Série 12 10: 565-672.

Moss ST, Lichtwardt RW, Manier J-F. 1975. Zygopolaris, a new genus of Trichomycetes producing zygo- 
spores with polar attachment. Mycologia 67:120 127.

Santamaria S. 1997. Lancisporomyces, a new genus of Trichomycetes with lance-shaped zygospores. Mycologia 89:639-642.

Valle LG, Santamaria S. 2004. The genus Smittium (Trichomycetes, Harpellales) in the Iberian Peninsula. Mycologia 96:682-701.
White MM, Lichtwardt RW. 2004. Fungal symbionts (Harpellales) in Norwegian aquatic insect larvae. Mycologia 96:891-910.

Williams MC, Lichtwardt RW. 1987. Three new species of Smittium (Trichomycetes) with notes on range extensions. Mycologia 79:832-838.

- - 1990. Trichomycete gut fungi in New Zealand aquatic insect larvae. Can J Bot 68:1045-1056. 